\section{Fertility Management of Drip-irrigated Vegetables}

\section{T.K. Hartz' and \\ GJ. Hochmuth ${ }^{2}$}

Additional index words. trickle irrigation, nutrients, fertigation

Summary. Drip irrigation provides an efficient method of fertilizer delivery virtually free of cultural constraints that characterize other production systems. Achieving maximum fertigation efficiency requires knowledge of crop nutrient requirements, soil nutrient supply, fertilizer injection technology, irrigation scheduling, and crop and soil monitoring techniques. If properly managed, fertigation through drip irrigation lines can reduce overall fertilizer application rates and minimize adverse environmental impact of vegetable production.

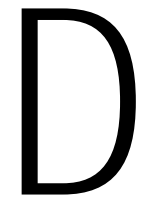
rip irrigation allows precise timing and uniform distribution of fertilizer nutrients. Improved efficiency results from small, controlled fertilizer applications throughout the season, in contrast to large preplant or early-season sidedress applications. Fertilizer application through drip irrigation (fertigation) can reduce fertilizer usage and minimize groundwater pollution due to fertilizer leaching from rain or excessive irrigation. Significant technical skill and management are required to achieve optimum performance. The following discussion highlights the main elements of formulating and evaluating a fertigation plan.

'Department of Vegetable Crops, University of California, Davis, CA 95616.

${ }^{2}$ Horticultural Sciences Department, University of Florida, Gainesville, FL 32611.

The cost of publishing this paper was defrayed in part by the payment of page charges. Under postal regulations, this paper therefore must be hereby marked advertisement solely to indicate this fact.

\section{Soil nutrient supply}

Proper fertigation management begins with knowledge of the nutrient status of the soil. Most soils contain substantial quantities of available macronutrients and arefrequently sufficiently supplied with micronutrients; using a standard drip fertigation program without soil testing will often lead to wasteful fertilizer application and, less frequently, result in a nutrient deficiency. Analytical procedures for soil analysis differ widely from location to location; it is important to use a laboratory using test procedures calibrated for the geographic area of interest.

Mineral $\left(\mathrm{NO}_{3}-\mathrm{N}\right.$ and $\left.\mathrm{NH}_{4}-\mathrm{N}\right)$ and organic forms of $\mathrm{N}$ are present in all soils. Analysis for mineral $\mathrm{N}$ often is confined to $\mathrm{NO}_{3}-\mathrm{N}$, because in most situations $\mathrm{NH}_{4}-\mathrm{N}$ constitutes $<20 \%$ of mineral $\mathrm{N}$ content. Estimating the rate at which soil organic $\mathrm{N}$ is mineralized is problematic, but $\mathrm{N}$ mineralization potential can be important; net $\mathrm{N}$ mineralization rates of 0.5 to $2.0 \mathrm{~kg} \mathrm{~N} /$ ha per $d$ are common (Magdoff, 1991). Provided that the soil is drained adequately, mineralization potential generally increases with increasing organic $\mathrm{N}$ content; a low $\mathrm{C} / \mathrm{N}$ ratio of recently incorporated plant residues and organic amendments also will favor more rapid mineralization.

Unlike $\mathrm{NO}_{3}-\mathrm{N}$, availablesoil $\mathrm{P}$ and Kexist in chemical equilibrium with slowly availableforms. The most appropriate soil test procedures vary depending on location and soil characteristics. In the southeastern United States, acidic sandy soils usually are assayed for $P$ and Kusing the Mehlich I soil test (Hanlon et al., 1990). Neutral or alkaline mineral soils in the western United States are extracted more appropriately by the bicarbonate and ammonium acetate techniques for $\mathrm{P}$ and $\mathrm{K}$, respectively (Reisenauer, 1983). Mineral soils in the western United States commonly contain sufficient $K$ for maximum vegetable production and, where heavy fertilization has been used over years, sufficient $P$ as well. Soil supply of $K$ is generally morelimited in the southeastern United States; however, $\mathrm{P}$ has accumulated to high levels in many soils used repeatedly for vegetable production.

\section{Crop nutrient requirements}

Vegetablecrops differ widely in their macronutrient requirements and in the pattern of uptake over the growing season. In general, N, P, and K uptake follows the same course as the rate of crop biomass accumulation. Fruiting crops such as tomato, pepper, and melon require relatively little nutrition until flowering, when nutrient uptake accelerates, peaking during fruit set and early fruit bulking. As fruit mature, macronutrient requirement declines. Nonfruiting crops such as celery, lettuce, and cole crops have slow nutrient uptake through the first half of the season; the rate of nutrient acquisition accelerates until just before harvest. Fertilization recommendations, based on research conducted regionally or locally, vary considerable among areas of the United States; it is important to recognize these regional difference when formulating a fertigation program.

\section{Nutrients applied through drip irrigation systems}

Although most nutrients can be injected successfully into drip irrigation systems, themostoften applied nutrients are $\mathrm{N}$ and $\mathrm{K}$. Crop requirements for $\mathrm{N}$ and $\mathrm{K}$ are large relative to other elements, and fertigation provides a system to supply the requirements of the crop in ascheduled fashion during the season. The leaching potential for $\mathrm{N}$ on most soils, and for $\mathrm{K}$ on sandy soils, makes split applications of thesenutrients through a drip system attractive for improving fertilizer efficiency. In addition, there are few precipitation and clogging problems associated with $\mathrm{N}$ or $\mathrm{K}$ injection.

Phosphorus, $\mathrm{Ca}, \mathrm{Mg}$, and micronutrients can be injected successfully into drip irrigation systems if precautions aretaken to mitigateagainst chemical precipitation. Analysis of irrigation water for $\mathrm{Ca}, \mathrm{Mg}, \mathrm{Fe}, \mathrm{pH}$, carbonate, and bicarbonate is important for predicting chemical precipitation problems; the risk of precipitation increases with increasing pHor increasing concentration of these materials. Acids may need to be injected with the fertilizer to maintain high nutrient solubility during fertilizer injection.

\section{Nutrient sources}

A variety of fertilizers can be injected into drip irrigation systems. Common $\mathrm{N}$ sources include urea-ammonium nitrate solutions, ammonium nitrate, calcium nitrate, and potassium nitrate. Potassium can be supplied from potassium chloride, potassium sulfate, potassium thiosulfate, or potassium nitrate. The choice of phosphorus products is more limited; phosphoric acid or ammonium phosphate solutions are used most commonly. Mono ammonium- or mono potassium phosphate are available, but are used infrequently.

The choice of fertilizer suitable for a specific application should be based on several factors: nutrient form, purity, solubility, and cost. The appropriate balance of $\mathrm{NO}_{3}-\mathrm{N}$ to $\mathrm{NH}_{4}-\mathrm{N}$ (or urea) depends on environmental conditions. In cool weather, $25 \%$ to $50 \%$ of applied N should bein the $\mathrm{NO}_{3}-\mathrm{N}$ form (Hochmuth and Hanlon, 1995). In warm weather, nitrification occurs rapidly, allowing greater use of ammoniacal-Nor ureafertilizers, which are significantly less expensive than nitrate fertilizers. All common $\mathrm{N}$ sources are available in clean, high-analysis, liquid solutions.

Solubility is an issue with potassium products, as are relative salt index and cost. Potassium chloride is inexpensive and reasonably 
soluble (solutions $>10 \% \mathrm{~K}$ are available), but relatively high in salt index. However, the salt index issue is generally not critical if the application rateis limited to the crop requirement. Potassium sulfate is less soluble and more expensive than potassium chloride, but it has a lower salt index. Potassium thiosulfateand nitratearehighly soluble but also are more expensive. Potassium chloride is used commonly for drip injection in the western United States, whereas potassium nitrate is popular in the southeastern United States. Although a topic of some controversy, there is no definitive research that documents a need to maintain a certain $\mathrm{N} / \mathrm{K}$ fertilizer ratio in vegetable production. As long as soil-test-predicted amounts of $\mathrm{K}$ are added, crop $\mathrm{K}$ requirements should be satisfied.
Liquid P fertilizers, except for food-grade phosphoricacid, may haveimpurities that complicate the al ready difficult task of eliminating chemical precipitation in the drip lines. However, with sufficient knowledge and attention to detail, fertilizer-grade phosphoric acid and ammonium phosphate solutions can be delivered successfully.

\section{Fertigation scheduling}

Efficient fertigation scheduling requires attention to three factors: crop- and site-specific nutrient requirements, timing nutrient delivery to meet crop needs, and controlling irrigation to minimize leaching of soluble nutrients below the effective root zone. Seasonal total N, P, and K requirements vary considerably by area and soil type (Hochmuth and Hanlon, 1995; Tyler and Lorenz, 1991). General recommendations should be adjusted based on soil test results to estimate seasonal application rates required for a particular field. In many situations a small percentage of $\mathrm{N}$ and $\mathrm{K}(20 \%$ to $30 \%)$ and most or all $\mathrm{P}$ is applied in a preplant broadcast or banded application. Preplant application of $\mathrm{N}$ (and $\mathrm{K}$, if needed) is particularly important where initial soil levels are low (Locasio et al., 1982, 1985) or in conditions where early-season irrigation is not required.

Preplant application of $P$ is common for several reasons. Soluble P sources (e.g., phosphoric acid) are more expensive than granular forms. The potential problem of chemical precipitation in the drip line is avoided. Also, the movement of drip-applied $\mathrm{P}$ away from the point of

Table 1. Injection schedules for mulched and drip-irrigated vegetables in Florida.

\begin{tabular}{|c|c|c|c|c|c|c|c|c|}
\hline \multirow[b]{2}{*}{ Crop } & \multirow{2}{*}{$\begin{array}{c}\text { Established } \\
\text { method }^{w}\end{array}$} & \multirow{2}{*}{$\begin{array}{l}\text { Typical bed } \\
\text { spacing (m) }\end{array}$} & \multicolumn{2}{|c|}{ Total nutrients $\left(\mathrm{kg} \cdot \mathrm{ha}^{-1}\right)^{2}$} & \multicolumn{2}{|c|}{ Crop development } & \multicolumn{2}{|c|}{ Injection rate $\left(\mathrm{kg} \cdot \mathrm{ha}^{-1} \cdot \mathrm{d}^{-1}\right)$} \\
\hline & & & $\mathrm{N}$ & $\mathrm{K}$ & Stage & Weeks $\mathbf{s}^{\mathrm{y}, \mathrm{x}}$ & $\mathrm{N}$ & $\mathrm{K}$ \\
\hline \multirow[t]{5}{*}{ Cantaloupe } & TP & 1.5 & 130 & 110 & 1 & 2 & 1.1 & 0.9 \\
\hline & & & & & 2 & 3 & 1.7 & 1.4 \\
\hline & & & & & 3 & 3 & 2.2 & 1.8 \\
\hline & & & & & 4 & 2 & 1.7 & 1.4 \\
\hline & & & & & 5 & 2 & 1.1 & 0.9 \\
\hline \multirow[t]{4}{*}{ Cucumber } & $S$ & 1.5 & 130 & 110 & 1 & 1 & 1.1 & 0.9 \\
\hline & & & & & 2 & 2 & 1.7 & 1.4 \\
\hline & & & & & 3 & 6 & 2.2 & 1.8 \\
\hline & & & & & 4 & 1 & 1.7 & 1.4 \\
\hline \multirow[t]{4}{*}{ Eggplant } & TP & 1.8 & 130 & 110 & 1 & 2 & 1.1 & 0.9 \\
\hline & & & & & 2 & 2 & 1.7 & 1.4 \\
\hline & & & & & 3 & 6 & 2.2 & 1.8 \\
\hline & & & & & 4 & 3 & 1.7 & 1.4 \\
\hline \multirow[t]{5}{*}{ Pepper } & TP & 1.8 & 180 & 150 & 1 & 2 & 1.1 & 0.9 \\
\hline & & & & & 2 & 3 & 1.7 & 1.4 \\
\hline & & & & & 3 & 7 & 2.2 & 1.8 \\
\hline & & & & & 4 & 1 & 1.7 & 1.4 \\
\hline & & & & & 5 & 1 & 1.1 & 0.9 \\
\hline \multirow[t]{5}{*}{ Tomato } & TP & 1.8 & 180 & 150 & 1 & 2 & 1.1 & 0.9 \\
\hline & & & & & 2 & 3 & 1.7 & 1.4 \\
\hline & & & & & 3 & 7 & 2.2 & 1.8 \\
\hline & & & & & 4 & 1 & 1.7 & 1.4 \\
\hline & & & & & 5 & 1 & 1.1 & 0.9 \\
\hline \multirow[t]{3}{*}{ Strawberry } & TP & 1.2 & 130 & 120 & 1 & 2 & 0.3 & 0.3 \\
\hline & & & & & 2 & Feb./Mar. & 0.8 & 0.7 \\
\hline & & & & & 3 & All other & 0.7 & 0.6 \\
\hline \multirow[t]{5}{*}{ Summer squash } & $S$ & 1.5 & 130 & 110 & 1 & 2 & 1.1 & 0.9 \\
\hline & & & & & 2 & 2 & 1.7 & 1.4 \\
\hline & & & & & 3 & 2 & 2.2 & 1.8 \\
\hline & & & & & 4 & 5 & 1.7 & 1.4 \\
\hline & & & & & 5 & 1 & 1.1 & 0.9 \\
\hline \multirow[t]{5}{*}{ Watermelon } & $S$ & 2.4 & 130 & 110 & 1 & 4 & 1.1 & 0.9 \\
\hline & & & & & 2 & 2 & 1.7 & 1.4 \\
\hline & & & & & 3 & 2 & 2.2 & 1.8 \\
\hline & & & & & 4 & 3 & 1.7 & 1.4 \\
\hline & & & & & 5 & 2 & 1.1 & 0.9 \\
\hline
\end{tabular}

Includes any starter fertilizer: $\mathrm{lb} / \mathrm{acre}=\mathrm{kg} \cdot \mathrm{ha}{ }^{-1 / 1.12 ;} \mathrm{K} / 0.83=\mathrm{K}_{2} \mathrm{O}$.

$y$ Where $20 \%$ of $N$ and $K$ have been applied as starter, Ninjection may be omitted for the first several weeks.

${ }^{x}$ For extended-season crops, N maintenance applications can proceed at 0.5 to $1.5 \mathrm{~kg} \cdot \mathrm{ha}{ }^{-1}$ per $\mathrm{d}$. Tissue testing should be used to fine-tune amounts.

wEstablishment method (seed or transplant) might affect the schedule. Transplanting shortens the growth cycle and the injection schedule by 1 to 2 weeks 
injection is governed mainly by soil texture and $\mathrm{pH}$. Movement of $\mathrm{P}$ is particularly limited in finetextured, alkaline soils. During the critical crop establishment period, $P$ banded near the developing seedlings may be used more efficiently. When making a preplant application of any nutrient it is important that the fertilizer be placed within the wetting zone of the drip system.

Once seasonal $N, P$, and $K$ requirements have been estimated and preplant application (if any) has been made, the balance of the fertilizer can be delivered through the drip system in multiple applications over the growing season. From crop nutrient uptake characteristics, one can apportion fertigation to meet nutrient requirements by crop growth stage. To calculate fertilizer application on the basis of daily or weekly need, one must account for the relative rate of crop development, which depends on temperature. Total seasonal crop nutrient requirements are relatively independent of environmental conditions. For example, an early spring melon crop will need roughly as much total $\mathrm{N}$ as a midsummer or fall crop, even though the length of the growing seasons (planting to harvest) will differ significantly.

Ideally, a crop-specific fertigation template could be developed using growing degree day (GDD) information. In practice, this is not often done. Alternatively, historical information on crop phenology can be used to construct general fertigation schedules (Table 1); these schedules are based on research and commercial grower experience in Florida (Hochmuth, 1992). For some crop groups, such as cucurbits, extrapolation of the nutrient program for one crop to another crop is possible. These schedules assume the soil will be supplying little of the crop $\mathrm{K}$ requirement. It is important to keep in mind that the actual fertilizer requirement may beconsiderably less, depending on soil test K levels. Similarly, crops grown on soils with high $\mathrm{N}$ supply capacity (high organic matter, significant residual mineral $\mathrm{N}$ content, etc.) also may require substantially less $\mathrm{N}$ fertilizer. These schedules also can be compressed or expanded depending on the length of the growing season.

Application of $\mathrm{N}$ and $\mathrm{K}$ in excess of crop requirements can have significant adverse consequences in addition to theadded fertilizer expense. Nitrate contamination of groundwater has become a serious environmental issue in some areas, and

Table 2. Sufficiency concentration ranges for plant leaf petiole fresh sap nitrate-nitrogen and potassium for Florida-grown vegetables.

\begin{tabular}{|c|c|c|c|c|c|}
\hline \multirow[b]{3}{*}{ Crop } & \multirow[b]{3}{*}{ Growth stage } & \multicolumn{4}{|c|}{ Nutrient concn } \\
\hline & & \multicolumn{2}{|c|}{$\begin{array}{l}\text { Petiole sap } \\
\left(\mathrm{mg} \cdot \mathrm{L}^{-1}\right)\end{array}$} & \multicolumn{2}{|c|}{$\begin{array}{c}\text { Whole-leaf } \\
\text { dry wt }\left(\mathrm{g} \cdot \mathrm{kg}^{-1}\right)\end{array}$} \\
\hline & & Nitrate-N & K & $\mathrm{N}$ & K \\
\hline \multirow[t]{3}{*}{ Broccoli and collard } & Six-leaf stage & $800-1000$ & $N A^{2}$ & $35-50$ & $35-45$ \\
\hline & Just before first harvest & $500-800$ & & $30-45$ & $15-40$ \\
\hline & First harvest & $300-500$ & & $30-40$ & $15-40$ \\
\hline \multirow[t]{3}{*}{ Cucumber } & First blossom & $800-1000$ & NA & $40-50$ & $20-30$ \\
\hline & Fruit $8 \mathrm{~cm}$ long & $600-800$ & & $25-50$ & $20-30$ \\
\hline & First harvest & $400-600$ & & $25-35$ & $15-25$ \\
\hline \multirow[t]{3}{*}{ Eggplant } & First fruit (5 cm long) & $1200-1600$ & $4500-5000$ & $45-55$ & $45-60$ \\
\hline & First harvest & $1000-1200$ & $4000-4500$ & $45-50$ & $35-50$ \\
\hline & Midharvest & $800-1000$ & $3500-4000$ & $35-45$ & $30-40$ \\
\hline \multirow[t]{3}{*}{ Muskmelon } & First blossom & $1000-1200$ & NA & $45-50$ & $50-60$ \\
\hline & First fruit $5 \mathrm{~cm}$ long & $800-1000$ & & $40-50$ & $45-50$ \\
\hline & First harvest & $700-800$ & & $35-45$ & $20-40$ \\
\hline \multirow[t]{5}{*}{ Pepper } & First flower buds & $1400-1600$ & $3200-3500$ & $45-50$ & $50-60$ \\
\hline & First open flowers & $1400-1600$ & $3000-3200$ & $40-45$ & $45-50$ \\
\hline & Fruit half-grown & $1200-1400$ & $3000-3200$ & $40-45$ & $40-50$ \\
\hline & First harvest & $800-1000$ & $2400-3000$ & $35-40$ & $35-45$ \\
\hline & Second harvest & $500-800$ & $2000-2400$ & $25-30$ & $30-40$ \\
\hline \multirow[t]{5}{*}{ Potato } & Plants $20 \mathrm{~cm}$ tall & $1200-1400$ & $4500-5000$ & $30-60$ & $35-60$ \\
\hline & First open flowers & $1000-1400$ & $4500-5000$ & $30-40$ & $30-50$ \\
\hline & $50 \%$ Flowers open & $1000-1200$ & $4000-4500$ & $30-40$ & $30-40$ \\
\hline & $100 \%$ Flowers open & $900-1200$ & $3500-4000$ & $25-40$ & $25-40$ \\
\hline & Tops falling over & $600-900$ & $2500-3000$ & $20-30$ & $15-30$ \\
\hline \multirow[t]{2}{*}{ Squash } & First blossom & $900-1000$ & NA & $30-50$ & $30-50$ \\
\hline & First harvest & $800-900$ & & $30-50$ & $20-30$ \\
\hline \multirow[t]{6}{*}{ Tomato (field) } & First buds & $1000-1200$ & $3500-4000$ & $30-50$ & $40-50$ \\
\hline & First open flowers & $600-800$ & $3500-4000$ & $35-40$ & $35-40$ \\
\hline & Fruit $2 \mathrm{~cm}$ in diameter & $400-600$ & $3000-3500$ & $35-40$ & $35-40$ \\
\hline & Fruit $5 \mathrm{~cm}$ in diameter & $400-600$ & $3000-3500$ & $30-40$ & $30-40$ \\
\hline & First harvest & $300-400$ & $2500-3000$ & $25-35$ & $25-35$ \\
\hline & Second harvest & $200-400$ & $2000-2500$ & $20-35$ & $20-30$ \\
\hline \multirow[t]{3}{*}{ Tomato (greenhouse) } & Transplant to second cluster & $1000-1200$ & $4500-5000$ & $40-60$ & $40-50$ \\
\hline & Second cluster to fifth cluster & $800-1000$ & $4000-5000$ & $40-50$ & $35-40$ \\
\hline & Harvest season (Dec.-June) & $700-900$ & $3500-4000$ & $35-40$ & $25-35$ \\
\hline \multirow[t]{4}{*}{ Watermelon } & Vines $15 \mathrm{~cm}$ long & $1200-1500$ & $4000-5000$ & $50-60$ & $40-50$ \\
\hline & First fruit $5 \mathrm{~cm}$ long & $1000-1200$ & $4000-5000$ & $40-50$ & $35-40$ \\
\hline & Fruit one-half mature & $800-1000$ & $3500-4000$ & $35-40$ & $25-35$ \\
\hline & At first harvest & $600-800$ & $3000-3500$ & $30-40$ & $20-30$ \\
\hline
\end{tabular}


excessive fertigation increases $\mathrm{NO}_{3}-\mathrm{N}$ leaching loss (Pier and Doerge, 1995; Thompson and Doerge, 1995). Heavy N application, particularly when $\mathrm{NH}_{4}-\mathrm{N}$ predominates, can induce blossomend rot in crops like tomato and pepper and stimulate vegetative growth at the expense of fruit yield. Excessive $K$ fertilization has been shown to reduce specific gravity of potato and size of strawberry fruit (Hochmuth et al, 1993; Albregts et al., 1996).

Nutrients can beinjected at various frequencies (daily to bimonthly), depending on system design constraints, soil type, and grower preference. Frequentinjection might beneeded on sandy soils that do not retain large amounts of nutrients, and for growers who want to minimize injection pump size and cost.

Fertigation frequency, in most situations, is not as important as achieving a correct rate of application of nutrients to the crop during a specified period (Cook and Sanders, 1991; Locascio and Smajstrla, 1989). Somegrowers find it easy to fertigate with each irrigation using automated controls, which places small amounts of nutrients at risk of leaching during any single leaching event. Since leaching is possible with drip irrigation, nutrients applied in any irrigation must not be subjected to excessiveirrigation either during that application or in subsequent irrigations.

It is possible to inject nutrients in noncontinuous (bulk) or continuous (concentration) fashion. For bulk injection, drip irrigation systems always should be brought up to operating pressure before injecting any fertilizer or chemical. Fertilizer should beinjected in aperiod such that enough time remains to permit completeflushing of thesystem without overirrigation. On sandy soils in Florida, an overall irrigation cycle of $45 \mathrm{~min}$ (young crop) up to $1.5 \mathrm{~h}$ (mature crop) would be sufficient (assuming today's typical drip tube flow rates) to apply the amount of water required by a tomato crop during any one irrigation cycle (Clark et al., 1990; Smajstrla et al., 1985). Irrigation cycles $>1.5 \mathrm{~h}$ for a mature crop on sandy soils run the risk of leaching nutrients and moving water below the root zone. Longer irrigation cycles can be used effectively on soils with high water-holding capacity. More detail on injection calculations and periods is available (Clark et al. 1990; Hochmuth and Clark, 1991). It is very important to design the system and fertilizer injector so that injection and flushing can be achieved in a reasonable amount of time without running the risk of overwatering the crop simply to apply the fertilizer.

In some systems, fertilizer is injected continuously (concentration injection) so that all irrigation water applied contains nutrients. This is acceptable as long as no irrigation cycle is so long that nutrients are leached below the root zone. During rainy periods, a bulk injection of a larger amount of fertilizer might be needed to fertilize a crop when no water is required.
Water management is integrally linked to fertigation management. Water that moves below the active crop root zone can carry $\mathrm{NO}_{3}-\mathrm{N}$ (and, in very sandy soils, $\mathrm{K}$ ) in substantial quantities. One centimeter of leachate at $100 \mathrm{mg} \mathrm{NO}_{3}-\mathrm{N} / \mathrm{L}$ would contain $10 \mathrm{~kg} \mathrm{~N} / \mathrm{ha}$. Indeed, one of the major advantages of polyethylene bed mulch (frequently used in conjunction with drip irrigation) is the reduction of $\mathrm{NO}_{3}-\mathrm{N}$ leaching with precipitation, but that advantage can be negated by excessive drip irrigation. Conversely, in some areas well water used for drip irrigation contains a significant concentration of $\mathrm{NO}_{3}-\mathrm{N}$; in regions such as the Salinas Valley, Calif., $\mathrm{NO}_{3}-\mathrm{N}$ levels of 10 to 20 $\mathrm{mg} \cdot \mathrm{L}^{-1}$ are common. Irrigating acrop with atotal of $30 \mathrm{~cm}$ of water at $15 \mathrm{mg} \mathrm{NO}_{3}-\mathrm{N} / \mathrm{L}$ would add about $45 \mathrm{~kg} \mathrm{~N} / \mathrm{ha}$.

\section{Nutrient monitoring}

The fertigation scheduling approach outlined above should, in most situations, supply adequate nutrition; however, monitoring soil and/ or plant nutrient status is the essential safeguard to ensure maximum crop productivity. In conventional production, soil $\mathrm{NO}_{3}-\mathrm{N}$ testing usually has been limited to preplant sampling; since drip irrigation provides the ability to add $\mathrm{N}$ at will, more extensive $\mathrm{NO}_{3}-\mathrm{N}$ monitoring is justified. Traditional soil sampling and laboratory analysis offer themost complete, accurateinformation, butgrowers are not likely to go to the effort and expense of this technique on an ongoing basis through a cropping cycle.

There are several alternative techniques to aid on-farm $\mathrm{N}$ measurement. One approach is the use of soil solution access tubes, also called suction lysimeters. These devices are simply porous ceramic cups, similar to tensiometer cups, attached to hollow access tubes. The units are installed in the field with the ceramic tips in the active root zone. To collect a sample, a vacuum is applied which draws water from the surrounding soil into the tube. This soil water sample is collected and analyzed for $\mathrm{NO}_{3}-\mathrm{N}$ content; most mineral $\mathrm{N}$ is usually in the nitrate form.

The use of suction lysimetry has serious limitations. There can be large spatial variability; one portion of a field may vary from another and, since $\mathrm{NO}_{3}-\mathrm{N}$ moves with the wetting front, there can be stratification of $\mathrm{NO}_{3}-\mathrm{N}$ within the bed. This problem can beminimized by using multiplelysimeters per field, but that also greatly increases the effort required, and the cost. Interpretation of results is also problematic. Extensive field data is lacking, but in general, a root zone soil solution $\mathrm{NO}_{3}-\mathrm{N}$ concentration $>75 \mathrm{mg} \cdot \mathrm{L}^{-1}$ indicates that sufficient $\mathrm{N}$ is available to meet immediate plant needs. A lower $\mathrm{NO}_{3}-\mathrm{N}$ concentration cannot be interpreted directly as $\mathrm{N}$ deficiency, given the difficulty of obtaining a sample representative of thewholeroot zone. Plant tissueanalysis would be warranted to confirm crop $\mathrm{N}$ status.
Another simpletechniquefor estimating soil nitrate concentration is the quick test procedure described by Hartz (1994). This test has theadvantage of measuring $\mathrm{NO}_{3}-\mathrm{N}$ in a composite soil sample representative of the root zone, compared to thesite-specificmeasurement of asuctionlysimeter. Soil and the $\mathrm{NO}_{3}-\mathrm{N}$ extracting solution are measured volumetrically, eliminating the need to dry or weigh soil. The moisture content of soil will affect the test, but moisture content of drip-irrigated soils generally will fall in a relatively narrow range, so the impact will be minor in most cases. Adjusting the test based on soil texture (hence, water-holding capacity) will improve accuracy. In general, soil $\mathrm{NO}_{3}-\mathrm{N}$ values above $20 \mathrm{mg} \cdot \mathrm{L}^{-1}$ indicate sufficient available $\mathrm{N}$ to meet immediate plant needs.

Reliance on soil $\mathrm{NO}_{3}-\mathrm{N}$ testing is most appropriate early in the crop cycle, when crop $\mathrm{N}$ uptake rate is low and the detection of substantial residual $\mathrm{NO}_{3}-\mathrm{N}$ can lead to reduced additional $\mathrm{N}$ fertigation. By midseason, crop uptake rates increase and soil $\mathrm{NO}_{3}-\mathrm{N}$ concentration correspondingly will change more rapidly. Also, once an extensive root system is developed, many crops can take up $\mathrm{N}$ in excess of crop needs (luxury consumption); low late-season soil $\mathrm{NO}_{3}-\mathrm{N}$ does not necessarily reflect $\mathrm{N}$ deficiency. From midseason until harvest, plant tissue analysis should be the primary indicator of $\mathrm{N}$ status, although soil testing still may be used to identify fields where $\mathrm{NO}_{3}-\mathrm{N}$ levels remain high enough to delay additional $\mathrm{N}$ application.

Conventional plant tissueanalysis, in which tissue is dried, ground and analyzed chemically in alaboratory, is the most accurate way to determine crop nutrient status. Through decades of research, sufficiency guidelines have been developed for most important vegetablecrops. These guidelines have been published for vegetables in Florida (Hochmuth etal., 1991) and California(Reisenauer, 1983). Although not specifically developed for drip irrigation, these standards are still generally applicable. Unfortunately, laboratory analysis of dry tissue is relatively costly, and the time lag between sampling and obtaining results can be significant. In recent years there has been increasing interest in on-farm tissue testing, particularly for monitoring drip-irrigated fields. On-farm monitoring usually involves the analysis of $\mathrm{NO}_{3}-\mathrm{N}$ and $\mathrm{K}$ content of petiole sap; sap analysis for $\mathrm{PO}_{4}-\mathrm{P}$ is uncommon. Measurement techniques include colorimetric methods, $\mathrm{NO}_{3}-\mathrm{N}$ or $\mathrm{K}$ test strips (Hochmuth, 1994), or ion-specific electrode(Hartz et al., 1993; Vitosh and Silva, 1994). Although all methods can be used successfully, the ion-specific electrode is the most commonly used approach. Table 2 lists petiole sap $\mathrm{NO}_{3}-\mathrm{N}$ and $\mathrm{K}$ sufficiency ranges developed under Floridaconditions. These values are similar to those developed in California. The appropriate protocol for tissue collection, handling, and analysis is discussed by Hochmuth (1994). 


\section{Literature Cited}

Albregts, E.E., G.J. Hochmuth, C.K. Chandler, J. Cornell, and J. Harrison. 1996. Potassium requirements of drip-irrigated strawberry. HortScience (In press.)

Clark, G.A., A.G. Smajstrla, D.Z. Harman, and F.S. Zazueta. 1990. Injection of chemicals into irrigation systems: Rates, volumes and injection periods. Fla. Coop. Ext. Bul. 250.

Cook, W.P. and D.C. Sanders. 1991. Nitrogen application frequency for drip irrigated tomatoes. HortScience 26:250-252.

Hanlon, E.A., G. Kidder, and B.L. McNeal. 1990. Soil, container media, and water testing. Fla. Coop. Ext. Circ. 817.

Hartz, T.K. 1994. A quick test procedure for soil nitrate-nitrogen. Commun. Soil Sci. Plant Anal. 25:511-515.

Hartz, T.K., R.F. Smith, M. LeStrange, and K.F. Schulbach. 1993. On-farm monitoring of soil and crop nitrogen status by nitrate-selective electrode. Commun. Soil Sci. Plant Anal. 24:2607-2615.

Hochmuth, G.J. 1994. Sufficiency ranges for nitrate-nitrogen and potassium for vegetable petiole sap quick tests. Hort Technology 4:218-222.

Hochmuth, G.J. 1992. Fertilizer management for drip-irrigated vegetables in Florida. Hort Technology 2:27-32.

Hochmuth, G.J. and G.C. Clark. 1991. Fertilizer application and management for micro (or drip) irrigated vegetables in Florida. Fla. Coop. Ext. Spec. Ser. SS-VEC-45.

Hochmuth, G.J. and E.A. Hanlon. 1995. Commercial vegetable crop nutrient requirements. Fla. Coop. Ext. Circ. SP-170.

Hochmuth, G.J., D. Maynard, C. Vavrina, and E. Hanlon. 1991. Plant tissue analysis and interpretation for vegetable crops in Florida. Univ. Fla. Coop. Ext. Spec. Ser. SS-VEC-042.
Hochmuth, G.J., E. Hanlon, G. Kidder, S. Hensel, W. Tilton, J. Dilbeck, and D. Schrader. 1993. Fertilization demonstrations for the tri-county potato production area of northeast Florida. Proc. Fla. State Hort. Soc. 106:190-198.

Locascio, S.J. and A.G. Smajstrla. 1989. Dripirrigated tomato as affected by water quantity and Nand Ktiming. Proc. Fla. StateHort. Soc. 102:307309.

Locascio, S.J., S.M. Olson, F.M. Rhoads, C.D. Stanley, and A.A. Csizinszky. 1985. Water and fertilizer timing for trickle-irrigated tomatoes. Proc. Fla. State Hort. Soc. 98:237-239.

Locascio, S.J., J.M. Myers, and J.G.A. Fiskell. 1982. Nitrogen application timing and source for drip irrigated tomatoes, p. 323-328. In: A. Scaife (ed.). Proc. 9th Intl. Plant Nutr. Colloq., Warwick Univ., England.

Magdoff, F. 1991. Understanding the Madgoff pre-sidedressing nitrate test for corn. J. Proc. Agr. 4:297-305.

Pier, J.W. and T.A. Doerge. 1995. Concurrent evaluation of agronomic, economic, and environmental aspects of trickle-irrigated watermel on production. J. Environ. Qual. 24:79-86.

Reisenauer, H.M. (ed.) 1983. Soil and plant tissue testing in California. Univ. Calif. Bul. 1879.

Smajstrla, A.G., D.S. Harrison, and G.A. Clark. 1985. Trickle irrigation scheduling I: Durations of water applications. Fla. Coop. Ext. Bul. 204.

Thompson, T.L. and T.A. Doerge. 1995. Nitrogen and water rates for subsurface trickle-irrigated romaine lettuce. Hort Science 30:1233-1237.

Tyler, K.B. and O.A. Lorenz. 1991. Fertilizer guide for California vegetable crops. Univ. Calif., Davis, Dept. Veg. Crops Special Publ.

Vitosh, M.L. and G.H. Silva. 1994. A rapid petiole sap nitrate-nitrogen test for potatoes. Commun. Soil Sci. Plant Anal. 25:183190.

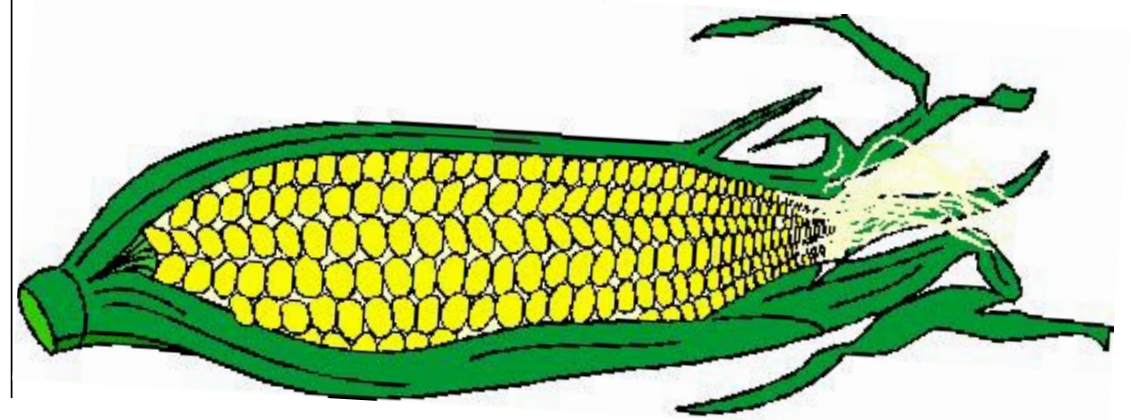

\section{Rowcover and High Tunnel Growing Systems in the United States}

\section{Aho S. Wells ${ }^{1}$}

Additional index words. crop protection, intensive production, season extension, spunbonded, plastics

Summary. Rowcovers and high tunnels are two intensive production systems used by commercial growers to extend the season and to improve yields of vegetables and strawberries. There are many types of rowcovers. These materials are summarized with descriptive information, primary use, and cost. The basics of high tunnel construction are presented to facilitate setting up a high-tunnel system.

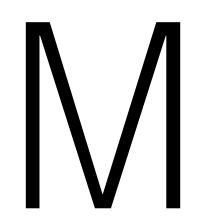

ost horticultural crops respond favorably to protection from environmental extremes, particularly in northern Unites States. Protective growing may include several cultural systems; however, this paper considers only two types of protective growing systems: rowcovers and high tunnels. There are many reports of the benefits of these systems nationally (Hochmuth, et al., 1993; Lamont, etal.; Matthews-Gehringer 1988; Purser, 1993; Soltani, et al., 1995; Wells and Loy, 1985; Wells and Loy, 1993) and internationally (Jensen and Malter, 1994; Wittwer and Castilla, 1995). Also, there are reports of expanded uses of rowcovers and high tunnels (Hancock and Simpson, 1995; Wells, 1995; Williams, 1994). The purpose of this paper is not to reiterate the benefits, rather to provide an overview of the types and uses of rowcovers and pictorial details on the construction and layout of high tunnels.

'Professor of plant biology, University of New Hampshire, Durham, NH 03824.

The cost of publishing this paper was defrayed in part by the payment of page charges. Under postal regulations, this paper therefore must be hereby marked advertisement solely to indicate this fact. 